\title{
Den rumænske folkevandring
}

\section{Steen Karlsen}

\section{Erfaringer fra andre emigrationslande viser at ud- viklingen kan vendes, så migranterne vender tilba- ge. Men det kræver, at de økonomiske og politiske reformer videreføres}

Piata Marachineanu ved den smukke Cismigu park kan blive en af $\mathrm{Bu}-$ karests mest fashionable adresser, hvis det ikke var, fordi den huser det rumænske arbejdsministeriums kontor for job i udlandet. Nat og dag året rundt venter store grupper af arbejdssøgende på pladsen og efterlader skrald, cigaretskodder og en klistret stank af sved og urin.

Her gennemføres årligt 50.000 jobsamtaler mellem rumænere og jobmæglere, der skaffer arbejdere til landbrug, byggeri, restauration og plejesektoren i Spanien og Tyskland, men der rekrutteres også til job i Italien, Israel, Qatar, De Forenede Arabiske Emirater og Ægypten. Hovedparten af jobbene er lavtlønnede, 5$6.000 \mathrm{kr}$. om måneden i tre til seks måneder. Mere end halvdelen af jobbene går til unge kvinder mellem 20 og 35 år.
Har man endelig fået plads i køen til kontoret, spiser man, sover, ryger og besørger, hvor man står. Her får man ikke sin plads tilbage, når man deltager i konkurrencen om de forjættede job.

Men de 50.000, der forlader Piata Marachineanu med et job i Vesten, er kun en brøkdel af de rumænere, der hvert eneste år forlader Rumænien for at bistå os med billig arbejdskraft. Hvert år forlader mellem en og to mio. rumænere landet $\mathrm{i}$ kortere eller længere tid, for at arbejde uden for landets grænser og en halv mio. rumænere har forladt Rumænien for et mere permanent ophold i Italien eller Spanien.

Efter kommunismens fald i december 1989 var Rumænien et forarmet land med et fravær af lovgivning og ubestikkelige myndigheder, der kunne få landet til at fungere in- 
den for en overskuelig tid. To uduelige regeringer op gennem 1990'erne fik ikke iværksat økonomiske og politiske reformer, der kunne fremme rumænernes tiltro til fremtiden.

Det har presset rumænske familier til at se, hvorledes man kunne skabe et økonomisk sikkerhedsnet under familien. Her er migration blevet et af de værktøjer, som familierne har taget i anvendelse. I fællesskab sørger man for, at et eller flere familiemedlemmer har et job uden for Rumænien, samtidig med at de sender penge hjem for at sikre familien.

\section{Hvorfor Tyskland?}

Tyskland blev det første mål for en en kvart mio. arbejdssøgende migranter. Men hvorfor begynder rumænere at bevæge sig til et fjernt og ukendt Tyskland?

Svaret findes i en meget lidt kendt historie fra den Kolde Krig. En historie om menneskehandel, mellem den rumænske stat på den ene side og den vesttyske stat og USA på den anden. For penge og handelsmæssige begunstigelser i forhold til USA fik en kvart mio. etniske tyskere bosat i Rumænien lov til at rejse til Vesttyskland fra 1950'erne til 1989.

De rumænske migranter var de etniske tyskeres naboer. De kom fra de samme egne og byer i Rumæniens grænseområder til Serbien, Ungarn og Ukraine samt fra Transsylvanien i den centrale del af landet.
Hvad var mere naturligt end at følge i sine naboers fodspor, når rumænerne gennem uformelle informationskanaler vidste, at man kunne få arbejde og bolig i Tyskland.

Migrationshistorien til Tyskland sluttede for hovedparten af den kvarte mio. rumænere og sigøjnere med, at der i 1993 blev indgået endnu en menneskehandel. Den tyske stat betalte Rumænien for at tage de uheldige migranter retur. Samtidig modtog Tyskland knap 180.000 etniske tyskere fra Rumænien i perioden 1990 til 1995, hvorefter denne vandring ophørte.

For at runde den ukendte historie om menneskehandel og udvandring fra Rumænien mellem 1950 og 1989 af, så købte Israel mere end en kvart mio. jøder fri, og mere end 75.000 etniske ungarere rejste til Ungarn. Kun sigøjnerne havde ingen stat eller pressionsgrupper, der hjalp dem væk fra Rumænien.

\section{Nye mål}

Ansporet af økonomisk krise og politisk kaos i 1990'erne og af at Tyskland var et lukket land, fik den rumænske migration nye mål. Der startede en vandring mod Italien og Spanien. Vandringen til Italien ansporedes af at rumænerne fik adgang til satellit-tv, udenlandske aviser, internet, og af at italienske biznizmand investerede i Rumænien. Til overraskelse for mange rumænere viste det sig, at italiensk er let at 
forstå, og at kulturerne er beslægtet med hinanden.

Migrationen til Spanien startede mere tilfældigt. Egentlig var målet for de unge rumænske mænd USA. Men de endte i stedet i Barcelona, Madrid eller andre spanske byer, hvor de erfarede, at sprog, kultur og religion matchede hinanden. Migrationen blev hjulpet på vej af et økonomisk boom, der fik spanierne til at vandre fra land til by og derved efterlod en mængde job som tomat-, frugt- og bærplukkere ubesatte, samt et boom inden for byggeri og voksende marked for lav kvalificerede tjenesteydelser.

I løbet af 1990'erne blev der lagt et grundlag for kædemigration fra Rumænien til Italien og Spanien, en migration der i dag har ændret sig fra at være midlertidig til at blive permanent, da en halv mio. rumænere i dag har fået legaliseret deres ophold i de to lande.

Det seneste kapitel i den rumænske migrationshistorie startede i slutningen af 1990'erne, hvor unge studerende eller nyuddannede begyndte at forlade landet for enten at studere eller at skaffe sig et job på højere niveau i USA, Canada og Australien. Men de rumænske akademikere har ikke succes som migranter, fx er der kun 40 pct. af dem i USA, der har et job, der svarer til deres uddannelse.

Ifølge en undersøgelse foretaget af FN's migrationsorganisation IOM viser det sig også, at interessen for at migrere til USA, Canada og Australien er dalende, hvorimod interessen for at migrere til EU-området er stor. Så stor at England nu har startet en kampagne mod illegal rumænsk indvandring; men da Irland virker som magnet for rumænerne, må englænderne nok indstille sig på et stort antal illegale rumænere på kortere eller længere transitophold i landet.

\section{Migrationens følger}

I hele perioden fra 1990 til 2005 er Rumænien blevet mere og mere afhængig af de penge, der overføres fra udlandet. I 1990 var værdien af de såkaldte remittances 102 mio. USD, svarende til 88 USD pr. officielt migreret rumæner pr. måned; i 2005 var beløbet vokset til knap 4 mia. USD, hvilket svarer til 430 USD pr. officielt migreret rumæner pr. måned, og i begge tilfælde skal ses bort fra penge og andre værdier, der flyttes ind i Rumænien uden om det officielle banksystem.

I løbet af en 15-års periode har den rumænske migration medført, at:

- Både den rumænske stat, lokale samfund og familier i dag er afhængige af de penge, der overføres af rumænske migrantarbejdere, på legalt eller irregulært ophold $\mathrm{i}$ andre lande.

- Rumænien er blevet afhængig af modtagerlandenes migrationspolitik og accept af at modtage rumænske 
migranter som arbejdskraft inden for det sorte eller det grå arbejdsmarked.

- Modtagerlandene er på samme måde blevet afhængige af den rumænske arbejdskraft inden for landbrug, byggeri og service, ældrepleje, ved at have accepteret at et arbejdsmarked af lavtlønnede, lav kvalificerede og fysisk krævende job er blevet overladt til legale og illegale migranter fra (bl.a.) Rumænien.

Der findes ingen migrationserfaringer i Rumænien, der kan fortælle, hvordan landets migrationshistorie vil ende. Men erfaringer fra Italien, Spanien og Irland viser, at selv om de tidligere har været emigrationslande, så kan udviklingen vendes, så landene bliver mål for tilbagevenden af egne migranter og for migration fra andre lande.

Skal udviklingen vendes, så Rumænien får lignende erfaringer som Italien, Spanien og Irland, så er det nødvendigt, at landets politiske og $\varnothing$ konomiske reformer videreføres, så landet bliver attraktivt for uden- landske investorer. Samtidig med at landets befolkning kan få adgang til sociale sikringsordninger gennem private og statslige løsninger.

Det mest sandsynlige scenario er, at Rumænien bliver medlem af EU fra 2007, hvilket betyder, at Rumænien implementerer EU-direktiver som national lovgivning, og der vil være et fortsat pres på den rumænske regering og myndigheder for, at lovgivningen kommer til at fungere effektivt.

EU vil samtidig bidrage med omfattende midler til at udbygge landets infrastruktur med hensyn til veje, kloakering, skaffe lys/gas/vand til landsbyer og til opbygning af informationsteknologiske netværk. Så vil rumænsk migration antageligt stagnere over tid, og rumænske migranter vil begynde at vende tilbage til landet.

Steen Karlsen er forbundssekreter $i$ HK/Danmark 